\title{
Shaky Ground
}

Paul Walker

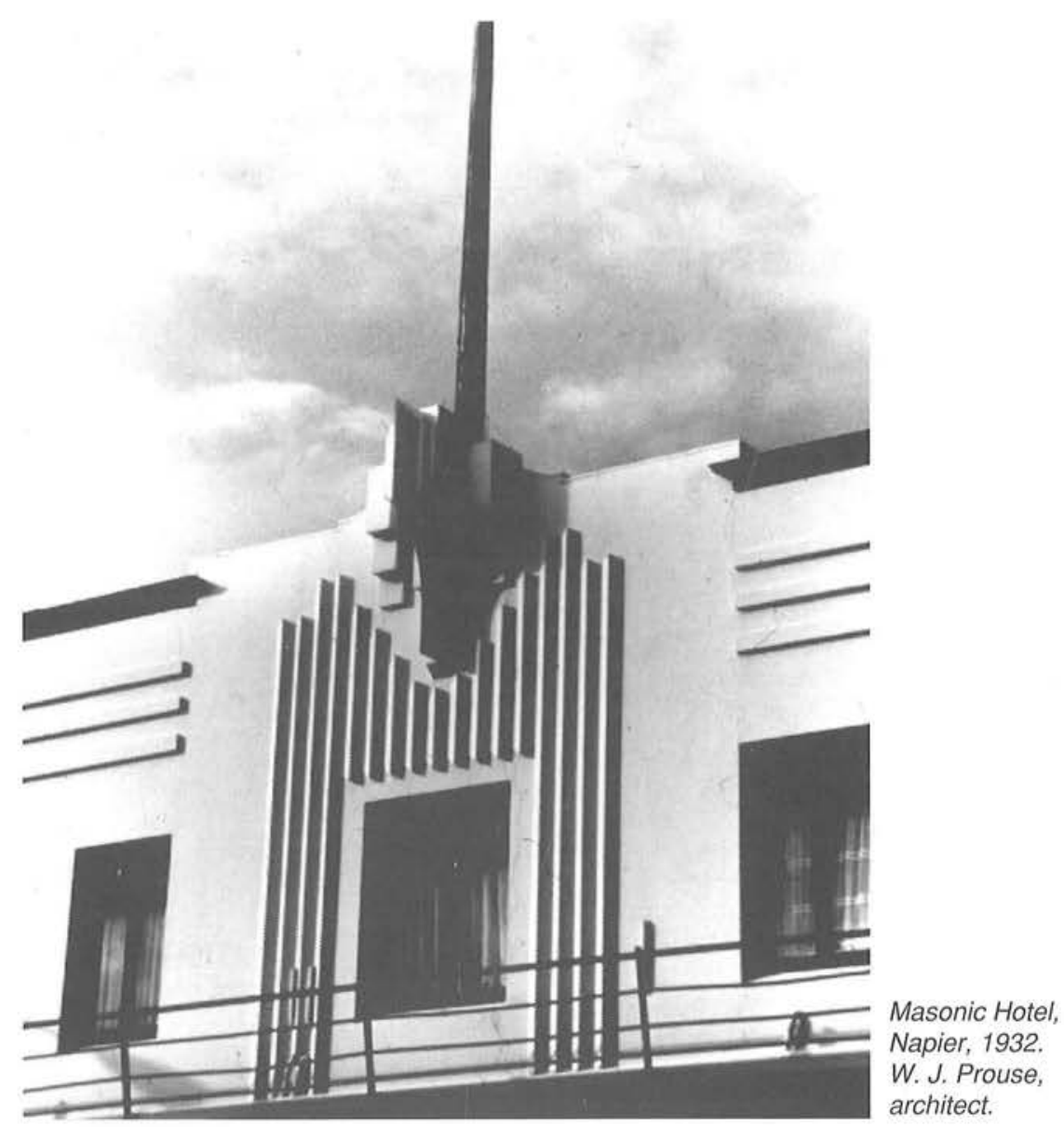

Why yet another book, where a seismic shuddering - one of the forms of the disaster lays waste to it?

- Maurice Blanchot

\section{Introduction: History and Semiotics}

In a commonly held view, a paradigmatic semiotics cannot concede any explanatory role to history. It cannot acknowledge change. Tafuri writes in "The Historical Project", the introduction to The Sphere and the Labyrinth:

The failure of a science of signs in general-of a semiology capable of translating one linguistic system into another-stands before us. One could try endlessly to relate Saussure's "system of differences" to that of architecture, of the physical environment, of nonverbal languages. One could try endlessly to exor- 
cise the uneasiness provoked by the perception of "epistemological breaks" by attempting to regain the innocence of archetypal symbols; the pyramid, the sphere, the circle, the ellipse, and the labyrinth could be installed as permanent structures of inexplicably changing forms, so that the archaeologist could placate his anxiety by recognising an "eternal return of the same." ${ }^{1}$

Umberto Eco's Theory of Semiotics offers a route out of this predicament by proposing that semiotics would study not only a theory of codes (of static structures) but also a theory of sign production. ${ }^{2}$ What Eco describes in his theory of sign production is a kind of rulegoverned creativity, the creativity being directed to a constant rewriting of the rules. Structure and event are bound together in a circular figure.

But in architecture, in Eco's account, this appears not to hold. Architectural history eludes semiotics. In his widely disseminated paper "Function and Sign: The Semiotics of Architecture" Eco specifically addresses change in the conventions that underwrite building, and though he writes there of the "dialectical interplay between forms and history ... structures and events" he finds that change seems to be precluded from architecture as a semiotic system. Architectural codes are sets of rules that cannot be used creatively:

... what stands out about these codes is that on the whole they would appear to be as communicative systems go, rather limited in operational possibilities. They are, that is, codifications of already worked out solutions, codifications yielding standardised messages - this instead of constituting, as would codes truly on the model of verbal language, a system of possible relationships from which countless significantly different messages could be generated. ${ }^{3}$

In the semiotic account, change can only occur in architecture from without, inexplicably, catastrophically, disruptively, disastrously. ("The disaster: break with the star, break with every form of totality... ."4)

But the discipline of history has recourse to figures of violence also. In "The Historical Project" Tafuri writes that history's objective is to "shatter the barriers that it itself sets up." 
History is always provisional, always subject to the violence of being rewritten. After Foucault, Tafuri describes criticism as a "language that should 'move and break up stones." The discipline of architectural history "ought to lead to the 'explosion' of the synthesis contained in the work wherever this synthesis is presented as a completed whole." And always there is the danger that this violence might be turned into ceremony, convention, myth, that "the language that should 'move and break up stones', is itself a 'stone' ... ."5

\section{The Napier Earthquake and Technocratic Discourse}

Bearing in mind these observations on architectural semiotics and architectural history, this paper will consider disaster and change. It will consider a literal mover and breaker-up of stone. Specifically it will consider one earthquake and ascribe to it a relationship to changes occurring in architecture in New Zealand in the 1930s. I refer to the earthquake that occurred in Hawke's Bay on February 3, 1931. It had a magnitude of 7.9 on the Richter scale, killed 258 people, and laid waste to the town centres of Napier (population: 16,000) and Hastings $(11,000)$. Subsequent fires exacerbated the destruction in both boroughs. Housing stock was also affected, mostly through the collapse of chimneys. Services in both towns-reticulated water, power, sewerage-were disrupted. Problems of water supply were particularly acute in Napier, and eighty per cent of the population there was afterwards evacuated. 6 Napier also suffered a major landslip from Bluff Hill, and to the west the Ahuriri Lagoon area was raised such that the lagoon emptied creating 2000 hectares of new land for the Harbour Board.

But beyond these bald facts the earthquake was "New Zealand's worst natural disaster;"7 it has become "a key event in the history of an earthquake prone land." 8 This is to say that it has been taken up into a realm of Barthesian mythology to which having assumed the 
proper name "Napier Earthquake" - it belongs rather more than it does to seismology. As a seismic event it shaped or reshaped parts of the Hawke's Bay and Poverty Bay landscapes; but in turn it has been fashioned to be part of a New Zealand mythos of struggle with and defeat of nature: "Nature precipitated the Hawke's Bay earthquake of 1931, but it was the men and women of Hawke's Bay, and those who came to their aid, who triumphed in the end." "Shared misfortune brought out the best in people and sparked off a spirit of cooperation."10

However, a cursory reading of the most thorough book about this disaster, G. Conly's The Shock of '31 (on which this paper draws extensively) reveals some less triumphant and cooperative aspects of the picture. Refugee camps, for example, were racially segregated by the Health Department on the grounds that "typhoid fever is common among natives and a large portion are chronic carriers of the disease."11 Nevertheless, Maori volunteers from the hinterland were welcome rescue workers in the stricken boroughs.

If racial discriminations were not displaced by the earthquake, and certainly gender ones were not (women who stayed tended to their families and the injured) nor were racial divisions erased. The chairman of the Hawke's Bay County Council is reported to have complained:

One hears, for instance, of refugees getting to Wellington and then being carried as far as Invercargill free. We hear of some of them coming back with wardrobes having travelled everywhere while the business people of Napier and Hastings stuck to their guns like heroes and the farmers to their properties....$^{12}$

And further indications of social restiveness can be seen in the meeting held in Napier in late February, a few weeks after the 'quake, to protest against charges introduced then for food relief. Walter Nash addressed those present. ${ }^{13}$ The parsimony of the authorities on this occasion was repeated later during the reconstruction period. 
All this suggests the idea that the disaster somehow brought the wider community together as a whole is not quite the case. But though a strong community of individual citizens did not emerge, a community of corporate interests did: government, industry and the professions.

Thus the entrepreneurial James Fletcher was quick to intervene. Fletcher saw the Prime Minister, George Forbes, a few days after the earthquake and travelled to Napier with him on February $10 .{ }^{14}$ Fletcher Construction had already secured contracts to erect a temporary building to be jointly used by all the Napier banks and for two buildings to be similarly shared in Hastings. They were opened a week later. These constructions were followed by a contract for the so-called "tin town" shopping centre, a group of 54 temporary shops erected at Clive Square, Napier, and opened on March 16. Fletchers went on to win a large portion of the reconstruction jobs-in both Hastings and Napier. The firm, says Conly, "became identified with the rebuilding,"15 and although, according to James Fletcher's biographer, it did not make substantial direct profits from this activity, nevertheless any retrenchment in the company's already substantial nationwide organisation was forestalled despite the economic depression, because of its involvement in the rebuilding programme.

But if the quake aftermath afforded an early opportunity to demonstrate how formidable the Fletcher organisation already had become in its ability to muster influence and resources, it seems just as telling that it was also an occasion in which the interests of private capital saw themselves as being directly aligned with the national good, such that they undertook directly to advise the government as an equal party. Thus, records Neil Robinson, "the important thing, James [Fletcher] felt, was to get the towns working again, to restore a sense of purpose to a bewildered people."16 This kind of alignment of corporate and state interests was to become much more pronounced in the housing programme of the first Labour government later in the decade. 
Business and government also formed rather more substantive ties than those of Fletcher and Forbes. In April 1931 the government passed the Hawke's Bay Earthquake Bill which set up an Adjustment Court and a Hawke's Bay Rehabilitation Committee. ${ }^{17}$ In this latter was vested power to dispense relief funds (which it did mostly in the form of loans.) The Committee included senior bureaucrats from Wellington, businessmen and so forth. Its chairperson was also one of two commissioners appointed by the government at the request of the Napier Borough Council to administer council affairs and exercise council powers. The Rehabilitation Committee worked in collaboration with a voluntary agency in Napier called the Napier Reconstruction Committee, consisting of, again, representatives from local bodies, businessmen, and professionals. ${ }^{18}$ Included was J.A. Louis Hay from the local branch of the New Zealand Institute of Architects. The Reconstruction Committee took advantage of extended powers granted the commissioners for the purposes of acquiring land for street widening to initiate wider ranging town planning initiatives. These initiatives were, however, still quite modest. Architect Stanley Natusch told the Wellington District Branch of the NZIA in March 1933:

... the original plan of Napier was quite sound and on reasonably good lines ... [But] several streets were widened and service lanes put in down the centre of large blocks. These service lanes gave access to the backs of shops for goods. They might also carry the sewage system, and underground telephones and electric light cables. ${ }^{19}$

The committee also considered sanitation and public health issues and it "... even considered cooperative ventures in the design of complete [city] blocks," 20 and though these were not to be taken further than a uniform building height, a homogenous look marked and continues to mark remade Napier. And even if the town may not have been in the event sketched out in a single gesture, much of the design work for new building was nevertheless done by architects in Napier, in Hastings too, on a collective basis. The volume of work necessitated cooperation, it was believed, ${ }^{21}$ but we can speculate that some coherent aesthetic was also 
a motivation.

The earthquake of course strengthened calls for more adequate by-laws to guard against losses of life and property. Interestingly, such suggestions had been voiced during the 1920s by the Institute of Architects and its members. A strong advocate in this regard was C. Reginald Ford, a partner in the firm which, under the style Gummer and Ford, was, in the view of many, probably the most distinguished practice to have operated in this country.

In 1925 Ford published a book titled Earthquakes and Building Construction. It was perhaps the first such book to appear in English dealing with the seismic performance of building structures. ${ }^{22}$ Model codes were initially put in place a few months after the 'quake in the

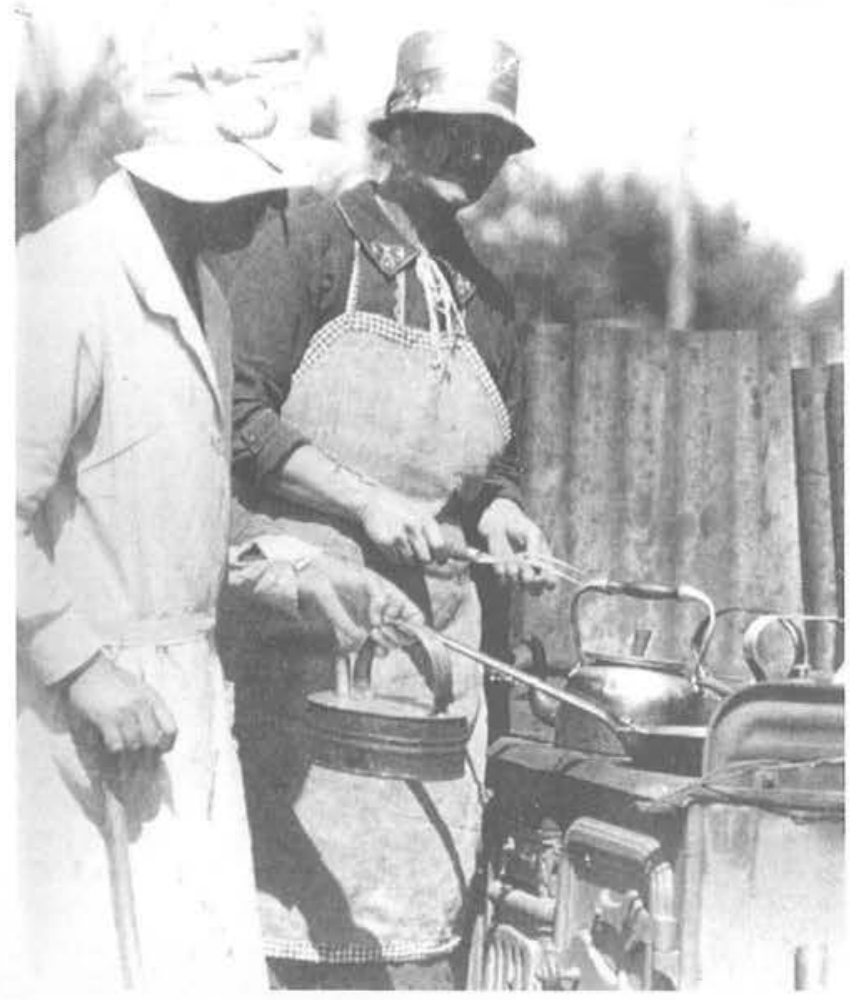
form of a temporary general earthquake building by-law devised by yet another expert committee, which also made proposals for a uniform building code to apply throughout New Zealand. This lead to the establishment of the Standards Institution, predecessor of the Standards Association; and of a Building Research Committee within the Department of Scientific and Industrial Research, forebear of the still extant Building Research Association. ${ }^{23}$

Now, all these cooperative activities that have been examined-the emergency building work of Fletchers; the 
planning activities of the Hawke's Bay Rehabilitation Committee, the Napier Reconstruction Committee, and the Associated Architects; the legislative measures promoted by the Building Regulations Committee-evidence a kind of paternalistic (fundamentally non-democratic) corporatism founded on technocratic competence. Such corporatism is essentially utopian. It strives for what Rowe and Koetter have called an activist utopia, Tafuri the utopia as project. ${ }^{24}$ And it is essentially modern. The legacy that the 1931 earthquake left architecture in New Zealand, then, is not merely a collection of buildings distinguished by art deco or Spanish mission ornamental motifs of more or less quality, but more importantly a discursive milieu marked by utilitarian and hygienist concerns.

\section{The Failure of Representation}

Perhaps more importantly still for architecture than the creation (or extensive reinforcement at least) of this new discursive and legal environment was a crisis of representation. This crisis was not restricted to architecture however. I have already related how the Napier Borough Council relinquished its authority to a commission appointed from Wellington. Local representative government was effectively suspended in both main Hawke's Bay towns. In the first instance at Hastings a solicitor by the name of Colonel Hildebrand Holderness assumed charge immediately after the earthquake in the absence of the mayor, delegating responsibilities to other ex-Wellington Regiment officers in the vicinity. One hundred and forty men were, for example, recruited for pickets and patrols, which-with the cooperation of the police and dressed in their military uniforms (white arm-bands added) - guarded every crossroads in the ruined business area with batons and pistols. In Napier, patrols (to supplement those provided by police, territorial soldiers and shore parties from HMS Veronica) were organised by former officers also, no doubt partly in response to a police telegram received there warning that criminals were coming from Auckland (sin city even 
then) to loot. ${ }^{25}$

A Napier Citizens' Control Committee was convened at a meeting of government ministers, Labour Party leaders, local body politicians, and business people in the town the day after the disaster. It lacked legal status until formally constituted a subcommittee of the Borough Council. The NCCC was in turn replaced by the commission mentioned earlier and the Reconstruction Committee.

While Holderness's unofficial militia worked alongside the Hastings Borough Council such that its work was absorbed into a general programme administered by officials of a democratically-elected organisation, control of local affairs in Napier did not return to a representative body until April 1933 when the Borough Council reassumed its authority. ${ }^{26}$

My view is that it is here in the breakdown of representational structures that the disastrous quality of the earthquake is properly to be located, not in the number of deaths or the material cost. The body count at Hawke's Bay was tragically high; but the 1918 influenza epidemic took more lives in the province and 6,700 deaths throughout New Zealand. ${ }^{27}$ It is hardly remembered in our mythology at all—where are the 'flu monuments? The destruction wrought by the earthquake was a severe economic burden, but in the midst of the misery of the Great Depression it could be seen in a different light:

Fifty years after the 1931 earthquake, a Hastings woman recollected thinking at the time: "It's an act of God of create work" ... While the earthquake "would ever remain one of their saddest memories", it was the depression and unemployment that really blighted their lives. ${ }^{28}$

But beyond the realm of government, disruption of representation occurred in economics too. The money economy of Hawke's Bay was in effect suspended by the direct distribution according to need of food, clothing and shelter. Trading activity was not re-established in Napier until the end of February. ${ }^{29}$ Land titles were another representational device de- 
feated by the 'quake, or, to be more precise, by the fire that subsequently burned in central Napier, the location of the Lands and Survey Department for the province. Survey plans and land title documents were destroyed. Duplicates held by owners usually burned too, deposited as mostly they had been with solicitors whose premises also were located in the central business areas. Further, land movements had dislocated survey pegs, reports Robert McGregor, and a new survey of the whole of Hawke's Bay had to be undertaken. ${ }^{30}$ Interim title certificates were issued (some are still in circulation) which after six years were deemed conclusive of ownership, but not as to boundaries, which is to say they were hardly conclusive at all. ${ }^{31}$

But it is in architecture and urbanism that the breakdown of representation was catastrophic. Those parts of the townscapes of Napier and Hastings which were most densely significative of communal life and those buildings which most represented shared values and meanings were the ones which were destroyed. The location of such townscapes and buildings was the town centre. ${ }^{32}$ It was at the town centre that architectural ornament was found, for it had always been a measure of the propriety of ornament that it was used to embellish those buildings privileged in the life of the community (accommodating privileged institutions) and those buildings gather at the centre. (Ornament has always been marked by the paradox of being both central and adjunct.) Buildings which collectively had the representational import "stability" all collapsed. Though this did cause institutional crises of the kind experienced by Lands and Survey, it should not be thought of as merely utilitarian dysfunction.

The case of the Hastings Post Office could be taken as paradigmatic here. After the earthquake that part of the building which housed postal services remained standing, damaged to be sure, but nevertheless recognisable (legible) as a building. But without its tower, which was ruined beyond any recognition, it is not clear what kind of building it might be. It signifies nothing. The construction of a new post office and a new tower as separate buildings perpetuated this failure of representation. Removed from daily life, the clock tower becomes 


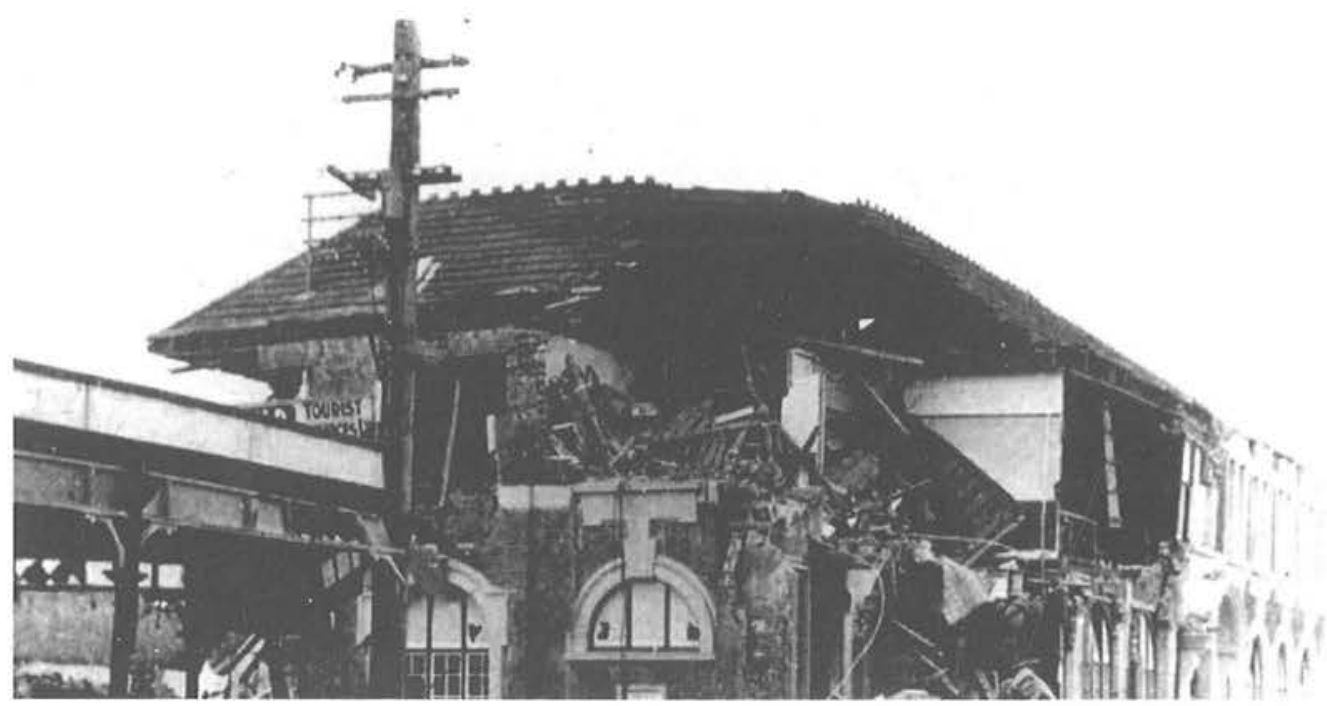

\section{Hastings Postoffice}

Feb. 1931

pure ornament, that is, ornament which transgresses its proper, auxiliary character. It has become Loosian in its strategy if, sadly, not quite Loosian in its execution. And the post office without architectural sign or character to distinguish its civic status, becomes a building without qualities (as the post office has recently become an institution without qualities,) essentially a modern building, a building among others similarly unforthcoming about their status or their role in the townscape's symbolic economy. Let me quote M.B. Boyd's description of rebuilt Hastings as further evidence of this semantic flattening: 33

Most new public and commercial buildings were inexpensive, reinforced concrete boxes of one or two storeys, strictly plain and functional. The most distinctive were the post office [I have exaggerated its poverty] and Edmund Anscombe's store for Westerman's which embodied new ideas of light and space. The Art Deco style of architecture imported from Europe and the United States prevailed, using horizontal lines with simple decoration around doors, windows and parapets which matched the long straight lines of the grid street system. A predominance of cream or pastel coloured walls, cantilevered shop verandahs, street awnings and large display windows enhanced the sunny, open, carnival atmosphere of the restored shopping centre. Low storeyed shop 
and office blocks, stubby chimneys and the decapitation of church towers and steeples added to the prevailing flatness of the emerging "City of the Plains." The Roman Catholic Church was the only remaining landmark.

This kind of thing was seen as desirable. The situation at Napier was more extreme since it was more extensively damaged than its rival. Even the governor general admired its homogeneity. ${ }^{34}$ There, the severance of representation and building was further refined as ornamental features such as arches and classical orders which would previously have been disposed across architectural surfaces and volumes were weaned from such a role and corralled in a kind of beautifully kept lawn cemetery of "symbolic forms", of monuments, along the Marine Parade which separates the centre of Napier from its foreshore. But any forms, not only those drawn from architectural traditions would do.

This, of course, is overstated. Building was not completely stripped of decoration and a capacity to mean and was not entirely dissociated from the realm of the symbol. The fact that the symbolic centre of the home, the chimney/hearth, was generally rebuilt testifies to this. (As the centre of either town collapsed, so did that of each house. The damage around was at both scales - domestic and urban - much less severe. ${ }^{35}$ Interesting, also, with respect to this was the alacrity with which new, temporary hearths were made, outside the house, to reestablish the home. ${ }^{36}$ ) The government carried the cost of rebuilding one chimney in each household; only one in four was not reconstructed. ${ }^{37}$ Napier's recent fame as a centre of art deco and Spanish mission style (thoroughly documented by Heather lves ${ }^{38}$ first, then by Shaw and Hallett) is also evidence of the survival of a conception of architecture as decorated building.

Nevertheless, ornament came to be suspect in New Zealand after the 1931 disaster. It was held to be dangerous. This did not occur only in the professional press where it would have been expected (and where it had already been occurring in the twenties). Conly writes: ${ }^{39}$

The Gisborne M.P., W.D. Lysnar, was particular[ly] concerned about the pedi- 
ments, parapets and other decoration which adorned buildings and which had been a main cause of death during the earthquake. "In Wellington," he told Parliament, "there are buildings with pediments and top hamper protruding three feet and four feet ... . In Gisborne, a single storey wall which carried an outward extension of nearly three feet of brick and concrete work, fell and killed a man on the footpath."

This could remind us of the many proscriptions of ornament that are to be found in the discourse of architectural modernism, though the imputed dangers are not usually physical ones. For Frank Lloyd Wright they were, however. Coincidentally, Wright published in 1931 a text titled "The Passing of the Cornice" in which he describes the collapse of the north wing of the Wisconsin State Capitol-while it was under construction-that he had witnessed as a young man. Workers were killed under the fallen rubble of the neo-classical edifice. $^{40}$

Now, if this particular FLW passage could hardly have been known in Napier or Hastings or New Zealand in the year of the Hawke's Bay earthquake, Wright's views and the views of others who were, like him, labelled modernists here, did have currency. For example, Wright's desire for an architecture that "would allow America to live its own life" in the machine age, uninhibited by the stylism that obsessed the nineteenth century, was reported (disparagingly to be sure, but accurately) in the NZIA Journal in 1930 in a long paper by Professor C.R. Knight of Auckland University College. ${ }^{41}$ (An extensive piece on European Modernism was included in the Journal in August 1928; 1929 saw-amazingly-some extracts from Le Corbusier's The City of Tomorrow. ${ }^{42}$ ) And it is known that Wright's views were well regarded by at least one Napier architect, Louis Hay, who, as was mentioned earlier, belonged to the Napier Reconstruction Committee. Reminiscing in 1967, Basil Ward who was articled in Hay's office around 1920 and who had a distinguished career as a modern architect in England in the 1930s wrote that Hay's "office was lined with books on 'Art Nouveau', also evidence of Austrian Secessionism, the Chicago School and Louis Sullivan, but in particular, Frank Lloyd Wright." 43 
It is clear that the proscriptions of ornament made after the earthquake were based on moral grounds. They echoed (unknowingly perhaps, but surely not incidentally) the similar injunctions of the moderns. Ornament is dangerous and should therefore be suppressed, if not altogether than at least to the point of being no more than a surface relief of chevrons and so on. Shaw and Hallett note the Napier Daily Telegraph's advocacy of a Californian Spanish style in the rebuilding because of its "... multifarious advantages, notably economy, simplicity and safety." 44 But it should be remembered that it was not ornament (or ornament alone, if at all) which was compromised, failed or acted improperly at Hawke's Bay. The failure was that of the structure which, supporting the ornamental supplement, was also supposed to support itself. Significantly, one of the few buildings in Napier that stood unscathed was the Public Trust Building with ostentatious embellishments of engaged doric columns. The properly supplementary, signifying character of ornament remained intact.

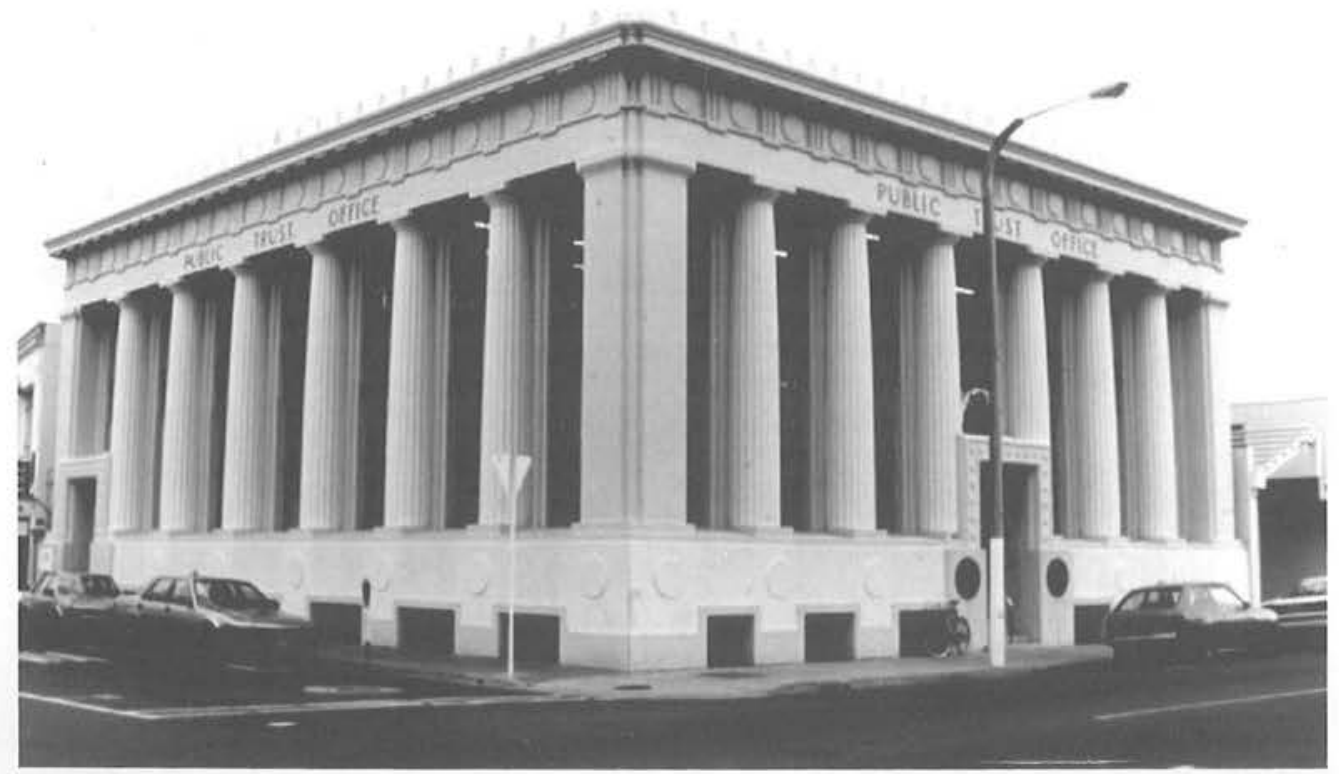




\section{Conclusion}

The Hawke's Bay earthquake gave impetus to the stripping of ornament and meaning from the built, pushed architecture nearer to the status of the empty sign of modernism. This empty sign was to be perfected by Ludwig Hilberseimer ${ }^{45}$ and very nearly approached here by many a self-conscious post-war modernist. Recall Boyd's description of the new Hastings. Such ornament as did survive in the residual decoration of deco eschewed any representational role. All buildings in the rebuilt districts of Napier and Hastings were adorned to a near equal degree. Deco as a style has no decorum, no sense: Harbison writes that it merely "echoes technological innovation fawningly." 46 Though it may borrow simplified and flattened classical elements it has no conceptual connection with classical ornament (ornament of the Western architectural tradition,) governed as this has been by notions of propriety, of appropriateness and related to a hierarchical distribution of privilege, prestige, and value among different building tasks from the temple down to the private dwelling. In the modern world, a world without qualities, in which all values are relativised, such hierarchies do not hold. The Napier earthquake dislodged them from the culture of architecture in New Zealand. Pre-modern architectural semiosis ends then.

I am suggesting therefore, bearing these comments regarding value, representation, and propriety in mind, and those made earlier regarding the formation of such modern discursive modes as utilitarianism and technocratic corporatism, that the Napier earthquake marks the beginning of modernism in New Zealand. There the shaky beginning of modern architecture can be found, founded.

To state this is to rewrite the history of architecture in New Zealand in such a way that the modern cannot simply be equated with a set of formal motifs or strategies, that can be spotted in their full array only in buildings dating from the end of the thirties at the earliest (though many of the formal traits of the modern-horizontality, simplicity, honesty of 
materials, etcetera-could be seen in the "tin town" shopping centre.) Further, to rewrite the history of the modern in this way is to do some violence to those histories which are already extant, Ian Lochhead's piece on New Zealand architecture in the 1930 s for instance, ${ }^{47}$ which holds that modern architecture arrived "late" here. It is also a questioning (more violence, more breaking of stones) of the view, put by Lochhead most succinctly, that the acceptance of the modern in New Zealand was conditional upon a recognition that it could be locally inflected. The regional inflections in the Hawke's Bay rebuild are, I believe, trivial-an admixture of Maori rafter patterns and deco at the Bank of New Zealand in Napier by Crichton, McKay and Haughton, reputed raupo leaves mixed with plaster roses at Hay's National Tobacco building at Ahuriri. ${ }^{48}$ (But perhaps one could see more indigenous echoes in all those deco diagonals-the chevron is, after all, important in Maori art, and maybe all the zigzags say "NZ NZ NZ ...!") The discourse of modernism is indifferent to the local.

My rewrite also does some violence to meta-histories recently proposed, which, modelled perhaps on Francis Pound's scornful essays about nationalism in New Zealand painting, 49 are also concerned with the local. I refer to Ross Jenner's statement that "in most thinking concerning building in New Zealand I believe we may see a certain set of metaphors concerned with the notion of a clean slate ... intended for the most part, to ground an architect of national identity." 50 Have we not known since Napier that architecture could not be grounded here? At the very least this position needs close interrogation, the ambivalent qualifications it includes need to be taken very seriously. Why was Corb being discussed in New Zealand in $1929 ?$

These histories and criticisms are not to be rejected, however. We have been taught to "multiply the 'beginnings,'" to acknowledge that histories are multiple and motivated by their contexts and by the legitimate or illegitimate concerns of the historian/critic. I became interested in the Napier earthquake not only because it yielded an opportunity to think of semiotics and history together, but because when I shifted to Wellington, another shaky 
place, I worked in an office located on the upper floor of an unreinforced load bearing brick building, located on reclaimed land and immediately adjacent to the main Wellington fault.

Curious about Napier, I could not help but wonder also what stones might be overturned by an earthquake in New Zealand now.

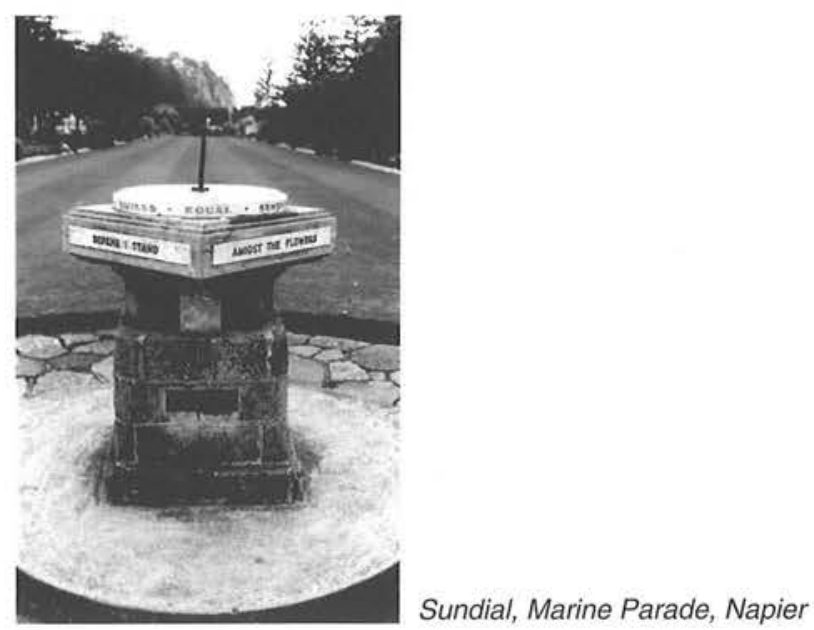

Notes:

1 Manfredo Tafuri, The Sphere and the Labyrinth, trans. Pellegrino d'Acierno and Robert Connolly (Cambridge Mass., 1987), p. 6.

2 Umberto Eco, A Theory of Semiotics (Bloomington, 1976).

3 U. Eco, "Function and Sign: the Semiotics of Architecture", in G. Broadbent, R. Bunt, and C. Jencks eds., Signs, Symbols and Architecture (Chichester, 1980), p. 39.

4 Maurice Blanchot, The Writing of the Disaster, trans. Ann Smock (Lincoln, Nebraska, 1986), p. 75. 
Tafuri, op. cit., p. 9.

G. Conly, The Shock of'31: The Hawke's Bay Earthquake (Wellington, 1980), p. 154.

Ibid., foreword.

Robert McGregor, The Great Quake (Napier, 1989), p. 2.

Conly, op. cit., p. 136.

Beverley Dunlop and Kay Mooney, Hawke's Bay (Auckland, 1986), p. 20.

Conly, op. cit. , p. 136

Cited by Conly, p. 163.

Ibid., p. 170.

Neil Robinson, James Fletcher: Builder (London, 1970), p. 107.

Conly, op. cit., p. 168.

Robinson, op. cit., p. 107.

Conly, op. cit., p. 180.

Ibid., p. 184.

Stanley Natusch, "The Rebuilding of Napier", New Zealand Institute of Architects Journal, April 1933, p. 21.

Peter Shaw and Peter Hallett, Art Deco Napier: Styles of the Thirties (Auckland, 1987), p. 7; Conly, op. cit., p. 173.

Shaw and Hallett, p. 8; M.B. Boyd, City of the Plains: A History of Hastings (Wellington, 1984), p. 269; Natusch, op. cit., p. 21.

Robert Park, "Development of Structural Design Procedures for Earthquake Resistance in New Zealand", Transactions of the Institution of Professional Engineers New Zealand, Vol 14, No 1, 1987, p. 23. My thanks to Andrew Charleson for drawing this article to my attention. 
Colin Rowe and Fred Koetter, Collage City, Cambridge Mass., 1978, p. 15; Manfredo Tafuri, "Ideology and Utopia", in Architecture and Utopia: Design and Capitalist Development, trans. Barbara Luigia La Penta (Cambridge Mass., 1976).

Conly, op. cit., p. 69.

Boyd, op. cit., pp. 261-263; Conly, pp. 146-159.

258 died in the earthquake, 296 in the epidemic. See Boyd, op. cit., p. 206; Max Lambert and Ron Palinski, The New Zealand Almanac (Wellington, 1982), p. 332.

Boyd, op. cit., p. 257; see also Conly, Hawke's Bay "Before" and "After" the Great Earthquake of 1931: An Historical Record (Napier, 1981).

Conly, (1980), p. 169.

McGregor, op. cit., p. 53.

Conly, op. cit., p. 169.

On the contemporary town centre, see Roland Barthes, "Semiology and Urbanism", V/A, Vol 2, 1973.

Boyd, op. cit., pp. 270-272.

Natusch, op. cit., p. 21.

McGregor, op. cit., p. 18.

Conly, op. cit., p. 210.

Ibid., p. 180.

Conly, op. cit., p. 210. repeats this story in his autobiography. Journal, October 1930. 
"Modernism in Architecture", New Zealand Institute of Architects Journal, August 1928; Le Corbusier, "The Great City", NZIA Journal, December 1929. This second article has been noted by Shaw and Hallett, (p. 15) who describe it however as being from a book called Trends in New Architecture.

Ward, "Connell, Ward and Lucas", in Dennis Sharp ed., Planning and Architecture: Essays Presented to Arthur Korn by the Architectural Association (London, 1967), p. 74.

Shaw and Hallett, op. cit., p. 8.

Tafuri, (1987), p. 221.

Robert Harbison, Eccentric Spaces (London, 1981), p. 53.

Lochhead, "New Zealand Architecture in the Thirties: The Impact of Modernism", Landfall, No 152, 1984. 